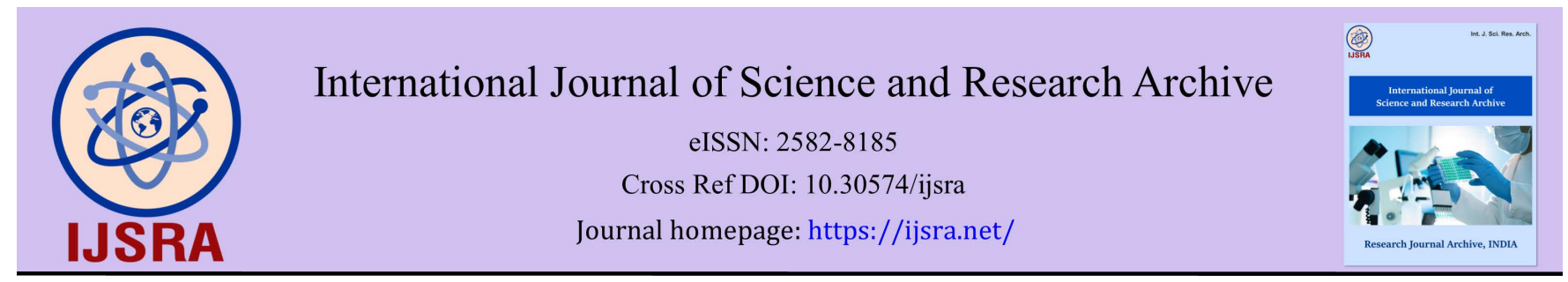

(REview ARTicle)

\title{
Community policing in Nigeria: A mere rhetoric than practical
}

\author{
Onuoha Ogobuchi Onuoha ${ }^{1,{ }^{*}}$, Joseph Ogbonnaya Alo Ekpechu ${ }^{2}$ and Mercy Chioma Arua ${ }^{3}$ \\ ${ }^{1}$ Department of Psychology/Sociological Studies Ebonyi State University, Abakaliki, Nigeria. \\ 2 Department of Sociology Alex Ekwueme Federal University, Ndufu-Alike, Ikwo. Ebonyi State, Nigeria. \\ ${ }^{3}$ Department of Criminology \& Security Studies Alex Ekwueme Federal University, Ndufu-Alike, Ikwo. Ebonyi State, Nigeria.
}

International Journal of Science and Research Archive, 2021, 02(02), 133-138

Publication history: Received on 29 March 2021; revised on 03 May 2021; accepted on 05 May 2021

Article DOI: https://doi.org/10.30574/ijsra.2021.2.2.0061

\begin{abstract}
This paper is designed to investigate into the various reasons to incorporate members of the community in Nigeria in the business of crime control thereby making them to be part and parcel of security outfit in their environs. This is premised on the grounds that with the involvement of the indigenes of the community in crime control and social disorder it will go a long way in checkmating crime. The paper will also dissect the reasons for introducing community policing and its benefits in creating an environment where crime cannot flourish. It is also expected to x-ray lapses in the current policing structure in Nigeria and why community policing will be like pouring water on a rocky ground. Finally, it will expose some salient areas to be addressed by the police in order to create a fertile ground for community policing to thrive.
\end{abstract}

Keywords: Community; Community policing; Crime control; Crime; Security

\section{Introduction}

Community policing as a form of policing is a process through which Community problems are identified and addressed by police officers in co-operation with the community members. It is a child of circumstance introduced by the police in the process of searching for an effective strategy to control crime and promote quality of life in the neighborhood (Onuoha, Oli \& Ikezue, 2020). It is believed to emerge as a response to the decline in public confidence in police and growing evidence that police forces could not fight crime by themselves alone without community involvement (Fridell, 2004; Innes, 2003; Skogan, 2006; Tilley, 2003; Virta, 2006 as cited in Onuoha, Oli \& Ikezue, 2020). Community policing also entails a collaborative effort between the police and the members of the community to identify the problems of crime and disorder and develop solutions within the community, thereby making the police more responsive and connected to the communities they serve. Rosenbaun (1989) observed that community policing is an idea that emerged in the mid-1980s when it was realized that formal and informal means of crime control or order maintenance were complementary and that community should work together to define "community crime prevention".

However, community policing can be traced to the introduction of community constables known as 'bobbies', by Sir Robert Peel in the newly created metropolitan London Police District during the early 19th century (Patterson, 2007). Sir Robert Peel rationalized that "the police are the public and the public are the police" (Fridell, 2004:4). This statement is believed to be the key principle of community policing and that police should not be separated from but rather joined in partnership with the community for effective crime control (Fridell, 2004). Community policing as a concept was first introduced in the United States in the 1960s to increase police-community contact and reduce the fear of crime (Cordner, 1999; Innes, 2003). It also suggests a policing philosophy or crime control strategies based on the notion that

\footnotetext{
${ }^{*}$ Corresponding author: Onuoha Ogobuchi Onuoha

Department of Psychology/Sociological Studies Ebonyi State University, Abakaliki, Nigeria.

Copyright (C) 2021 Author(s) retain the copyright of this article. This article is published under the terms of the Creative Commons Attribution Liscense 4.0.
} 
community interaction and support can help control crime and reduce fear, with community members helping to identify suspects, detain vandals and bring problems to the attention of police.

Community policing is not foreign or new to Africa, because long before European colonialism in Africa, the traditional Igbo society, for example, already had this model in place where the age grades and masquerade society among other roles performed the role of law enforcement (Okeke, 2013). Every adult male citizen was a member of the age grade and masquerade society, suggesting that policing or security was the duty of the entire society. Barbara (2006) observed that the establishment of community policing forums empowered by 1993 interim constitution marked the official introduction of community policing in South Africa. The forum is charged with monitoring the effectiveness and efficiency of the South Africa Policing Service, advising police on priorities in the neighborhood and promoting the accountability of the South Africa Police Service to local communities.

Community policing is perceived as an effective way of promoting public safety and to enhance the quality of life in a community. It was this search for an effective strategy to control crime and gain public confidence in the Nigeria Police which was hitherto in a sour relationship that necessitated community policing in Nigeria. To do this, the post-colonial policing in Nigeria have since witnessed numerous policing reforms. Siegel (2005) noted that in recent years, police departments have experimented with new forms of law enforcement including community policing. Preventing crime and reducing fear of crime are both closely related to rebuilding strong communities (Giddens, 2004). Maguire, Morgan and Reiner (2002) acknowledged that good police/public relationships are vital to successful policing. Without sustained public contact, officers would be unable to exercise their discretion appropriately and would find themselves isolated, increasingly hostile and unable to empathize with the public.

In view of this, seven senior officers from Nigerian police in 2003 went to U.K and U.S.A respectively to do a comparative study of community policing (Anucha, 2007). It was launched on the 27th day of April 2004 by the then Inspector-General of Police, Tafa Balogun during the era of President Olusegun Obasanjo administration and Enugu State was used as the pilot state (Anucha, 2007; Ikuteyijo, 2009). This effort of the Nigeria Police Force (NPF) to enhance community safety, involve communities in the job of policing and to make the security agency a people-friendly force that has received a boost with the training of 53 police officers at the police college, Ikeja (Okeke, 2013).

Furthermore, community policing in Nigeria presumes that there is need for better communication and understanding between the police and the public. Okeke (2013) noted that community policing is more effective in preventing offending and encouraging more liberal and tolerant attitudes towards offenders. According to him, It is presumed that the central theme of the Nigerian policing is that community model of policing is not only meant for uniform patrol or specific community policing units rather the potential rewards cannot be fully realized unless there is a shared understanding of the community towards that approach throughout police organization.

Additionally, the crux of community policing in Nigeria is that for members of the police force to fulfill the privileged role they perform in the society, they must be part of and not apart from the members of the communities they are serving. In line with this, Siegel (2000) observed that decision making about the community should involve the officer on the scene not a directive from central headquarter. By doing so, it will bring the police and citizens together to prevent crime and solve neighborhood problems. The Nigeria Police in their search for an effective strategy to control crime and gain public confidence in the Nigeria Police which was hitherto in a sour relationship necessitated community policing in Nigeria. To do this, seven senior officers from Nigerian police in 2003 went to U.K and U.S.A respectively to do a comparative study of community policing (Anucha, 2007). Just as Siegel (2005) noted that in recent years, police departments have experimented with new forms of law enforcement including community policing. It was launched on the $27^{\text {th }}$ day of April 2004 by the then Inspector-General of Police, Tafa Balogun during the era of President Olusegun Obasanjo administration and Enugu State was used as the pilot state (Anucha, 2007; Ikuteyijo, 2009). What is more, this effort of the Nigeria Police Force (NPF) to enhance community safety, involve communities in the job of policing and to make the security agency a people-friendly force that has received a boost with the training of 53 police officers at the police college, Ikeja (Okeke, 2013).

However, since the introduction of this new method in Nigeria in 2004 as a pilot project, the prospects of community policing in Nigeria look gloomy due to recurring cases of extorting motorists, complicity in crime, killing of innocent citizens, other lifestyles that discourage the public from cooperating with them. This strategy of policing is a lofty project but the fact remains that the Nigerian atmosphere is not ripe yet for it to work as it had worked in America and other developed countries. 


\section{Evaluation and Development of Community Policing}

Community policing has been evolving slowly since the civil rights movement in the 1990s exposed the weakness of the traditional policing model (Rosenbaum, 1989). Rosenbaum also noted that, even though its origin can be traced to this crisis in police-community relations, its development has been influenced by a wide variety of factors over the course of the past forty years.

The human rights movement of 1960s sparked off the improvements in police-community relations (Walker, 2001). Walker noted that widespread riots and protests against racial injustices brought government attention to sources of racial discrimination and tensions, including the police. He also observed the fact that police being a visible symbol of political authority, the police were exposed to a great deal of public criticisms and that not only were minorities underrepresented in police departments but studies suggested that the police treated minorities more harshly than the White citizens. Rosenbaum (1989) observed that team policing tried in 1960s and early 1970s, developed as a result of hostile relationship separating the police from the minorities was the earliest manifestation of community policing. Rosenbaum further maintained that in an attempt to facilitate a closer police community relationship, police operations were restructured according to geographical boundaries (community beats).

As a follow up, within the 1990s community policing had become a powerful national movement and part of everyday policing parlance (Skogan \& Hartnett, 1998). For them, community policing was encouraged by federal funds made available through the Office of Community Oriented Policing Services (COPS), police departments shifted attention implementing community policing reforms. Annual conferences on community policing became commonplace, and researchers began to study community policing programs in cities all over America. Besides the availability of funds and promising research findings, the political appeal of community policing and close affinity to long-term trends in societal organization contributed to the widespread acceptance of community policing (Skogan \& Hartnett, 1998).

At the onset of the twenty-first century, the momentum behind community policing shows no signs of slowing down. Zhao and Thurman (2003) observed that despite the fact that police departments may have been slow to adopt all the philosophical precepts, tactical elements, and organizational changes commensurate with the entire community policing model, its slow and steady evolution suggests that it is a permanent fixture on the landscape of American policing (Africa inclusive). But Nigeria joined the league of other nations of the world to embrace community policing in 2004.

\section{Benefits of Community Policing}

Community policing is believed to be an effective strategy to control crime, gain police-community confidence and create an environment where crime cannot flourish. In view of this, it enables police to develop improved policecommunity relationships (Segrave \& Ratcliffe, 2004). This provides the police with the opportunity to meet the community's needs (Ferreira, 1996), while increasing public accountability over police through participation (Skolnick \& Bayley, 1988; Palmiotto, 2000). There is strong anecdotal evidence suggesting that community policing has positive effects on police through increased job satisfaction and improved interaction with, and confidence in, the community (Mayhill, 2006; Patterson, 2007). Mayhill (2006) argues that community policing 'embeds' officers within the community where they become more understanding of the local situations and promote a positive image of police. This provides the officers with the opportunity to make positive community-police experiences and contacts, which is said to increase morale amongst police through the encouragement of a supportive and welcoming community (Palmiotto, 2000).

Furthermore, it is widely accepted that community policing increases the perceptions of safety and decreases the fear of crime. Skogan (2006) argues that there is evidence to suggest that increasing community-police interactions are associated with lower levels in fear of crime. However, police and the community have differing levels of perceptions of safety and it has been suggested that police are more likely to perceive a reduction in the fear of crime than the community (Sadd \& Grinc, 1996). Many evaluations have illustrated positive findings in reducing the fear of crime and increasing perceptions of safety. For example, the UK National Reassurance Policing Program (NRPP) measured specific indicators of safety which overall illustrated positive results (Tuffin, 2006). The Chicago Alternative Policing Strategy (CAPS) evaluation demonstrated a significant decrease in the community's perception of crime problems (Ferreira, 1996; Skogan \& Steiner, 2004). However, Skogan and Hartnett (1998) found that although the reduction in fear of crime as widespread, the impacts were inconsistent across different ethnic groups. 
Finally, community policing is beneficial as a policing approach to address a range of different crime, disorder and antisocial behaviour. For example, community policing approaches have been used to address graffiti and property damage to gang violence and organized crime (Skogan \& Hartnett, 1998). More recently it has been an approach adopted to deal with anti-terrorist activities in some communities (Pickering, Wright-Neville, McCulloch, \& Lentini, 2007).

\section{Challenges Facing Community Policing Implementation in Nigeria}

Despite the ever cherishing expectations of community policing in the control of crime and its fear, it has been beset with myriads of challenges. This has in no small way hampered the effective implementation of community policing in Nigeria, just like any other policy. As a result of this, lives and properties worth millions of naira have been lost occasioned by one form of crime or the other. Okeshola and Mudiare (2013) observed that despite numerous efforts by various police administrations to curtail the level of crime in Nigeria, crime and social disorder still persist in the country. They further noted that wide spread corruption in the Nigeria Police Force is fueling abuses against ordinary citizens and severely undermining the rule of law in Nigeria on a daily basis. Countless ordinary Nigerians are accosted by armed police officers who demand bribes and commit human rights abuses against them as a means of extorting money. These abuses range from ordinary arrest and unlawful detention to threats and acts of violence, including sexual assault, torture, and even extrajudicial killings (Human Rights Watch, 2010). Corruption exists in the Nigeria Police Force much the same way as it does in any other police organization the world over, except perhaps, in terms of its extent and the organization's reaction to it.

However, the issue of corruption in the Nigeria police as noted above cannot be treated in isolation of the larger society. Police routinely extort money from victims of crimes to initiate investigations and demand bribes from suspects to drop investigations. Corruption in the police is so endemic that it has eroded public trust and confidence they have in the police. To achieve any success in combating corruption in the Nigerian police one has to take a holistic approach and most importantly understanding the growth and existence of corruption within the police (Okeshola \& Mudiare, 2013). Furthermore, Onyeozili (2005) identified that institutional constraints constitute major challenges facing community policing implementation for effective crime control. This according to him proves that allegations leveled against the institution and its personnel, some of which have proven to be true, include arbitrariness in exercising its power, corruption, perversion of justice, and delays in the administration of justice. Various factors have been blamed as constituting a stumbling block to the effective administration of justice and efficient maintenance of law and order in Nigeria. Other factors are inadequate manpower (both in strength and expertise), insufficient education and training, inadequate equipment, and poor conditions of service of the average policeman. The long-term failure of the Nigerian authorities to address police bribery, extortion, and wholesale embezzlement threatens the basic rights of all Nigerians.

Another endemic problem in Nigeria, which the police still battle with, is Godfatherism. This according to Onyeozili (2005) is the funding and abetting of vices and shielding "connected" criminals from justice by government agents and highly placed officials entrusted with the power and authority to investigate and prosecute such vices. It has become a dominant issue in African polity and impedes the course of justice in virtually all the countries in Africa. Furthermore, many highly placed public officers in Nigeria are known to pervert the course of justice by the virtue of their closeness to the seat of power. Often, the police get sucked in, and this accounts for their complicity in several unresolved crimes across the country. In the same vein, the police as it is now came out of a military administration. That is probably the biggest challenge we face -turning it from a force into a service oriented.

Although, the police officers often lack the skills needed to police effectively, but refuse to admit the most serious allegations made about the police -that they brutally torture and sometimes kill suspects without-trial (Iwar, 2009). No wonder Ugwuoke (2010) proffered that the 'Force' attached to Nigeria Police is a reason for their forceful dealings with the public. Finally, the perception of both the police to the citizens they are meant to protect and citizens to the police are not something to write home about. To be frank, the image of police in the eyes of Nigerians is bad as mere mention of police put fear in people than expected hope.

\section{Conclusion}

This paper has in no small manner exposed numerous factors that led to the introduction of community policing in Nigeria, benefits of community policing, challenges of community policing that boils down to the reasons why community policing project in Nigeria is effort in futility. This is embedded on the fact that the current police structure in Nigeria is a colonial legacy which is rooted in brutality, violence, harassment of members of the public as that made them to lack public cooperation and acceptability. 


\section{Recommendation}

The paper therefore recommends that for community policing in Nigeria to be effective in combating crime and to enhance quality of life in the neighborhood, the government should organize programs aimed at bringing the community and police closer to aid in the crime prevention. Again, seminar on police/public attitudinal change should be organized in order to recognize and protect the dignity of human persons. Finally and most importantly is that the police should be civil, cooperative in their day to day dealings with the public and eschew corruption. These will smoothen the cooperation and perception of police by the public which is the precursor for effective community policing take off in Nigeria.

\section{Compliance with ethical standards}

\section{Acknowledgments}

All authors whose works were used are hereby acknowledged.

\section{Disclosure of conflict of interest}

There is no conflict of interest since the authors are from closely related disciplines and are conversant with current policing trends in the area.

\section{References}

[1] Anucha G. Community policing gets boost: COPS give special training. Daily Sun. 15 March 2007; 17.

[2] Barbara L. How community policing works. 2006.

[3] Cordner G. Elements of community policing. In Grains, L., \& Cordner, G. (Eds.). Policing perspectives: An Anthology. Los Angeles: Roxbury Publishing Company. 1999; 137-149.

[4] Ferreira BR. The use and effectiveness of community policing in a democracy. Policing in Central and Eastern Europe: Comparing Firsthand Knowledge with Experience from the West. College of Police and Security Studies, Ljubljana, Slovenia. 1996.

[5] Fridell L. The defining characteristics of community policing. In Fridell, L. \& Wycoff, M. (Eds.). Community policing: The past, present, and future Washington: Police Executive Research Forum. 2004; 3-12.

[6] Giddens A. Sociology (4th ed.). Uk: Polity Press. 2004.

[7] Human Right Watch. Police corruption in Nigeria. 2010.

[8] Ikuteyijo L. The challenges of community policing in Nigeria. International Journal of Police Science and Management. 2009; 3(11): 21-32.

[9] Innes M. Understanding social control: Deviance, crime and social order. New York: Mcgrew-Hill International. 2003.

[10] Iwar E. Can Nigeria's police be reformed? BBC News, Thursday 30th July. 2009.

[11] Maguire M, Morgan R, Reiner R. The oxford handbook of criminology (3rd ed.). U.S: Oxford University Press. 2002.

[12] Mayhill A. Community engagement in policing: Lessons from the literature. 2006.

[13] Okeke VOS. Community policing, vigilante security apparatus and security challenges in Nigeria: A lesson from Britain and Igbo traditional society of Nigeria. British Journal of Arts and Social Sciences. 2013; 5(11): 306-321.

[14] Okeshola FB, Mudiare PEU. Community policing in Nigeria: Challenges and prospects. American International Journal of Contemporary Research. 2013; 3(5): 134-138.

[15] Onuoha 00, Oli NP Ikezue CE. Residents' Awareness, Understanding And Support For Police-Community Partnership In Crime Control In Ishielu Local Government Area, Ebonyi State, South-East, Nigeria. American Journal of Humanities and Social Science Research. 2020; 4(5): 8-18.

[16] Onyeozili EC. Obstacles to effective policing in Nigeria. Journal of Criminal Justice Administration. 2005; 1(1): 27 34. 
[17] Palmiotto M. Community policing: A policing strategy for the 21st Century. Boston: Jones and Bartlett Publishers. 2000.

[18] Patterson J. Community Policing: Learning the Lessons of History. Lectric Law Library. Online]< http://www. lectlaw. com/files/cjs07. htm>(20 September 2011). 2007..

[19] Pickering S, Wright-Neville D, McCulloch J, Lentini P. Counter-terrorism policing and culturally diverse communities. Final Report 2007, Monash University. 2007.

[20] Rousenbaun P. Community crime prevention: A review of what is known. In Dennis, J.K.(Ed.). Police and policing: Contemporary New York: Praega. 1989; 203-215.

[21] Sadd S, Grinc R. Implementation challenges in community policing innovative neighborhood-oriented policing in eight cities. 1996.

[22] Segrave M, Ratcliffe J. Community policing: A descriptive overview. Australian: Institute of Justice Studies. 2004.

[23] Siegel L. Criminology (7th ed.). Belmont,CA: Thomson Wadsworth. 2000.

[24] Siegel L. Criminology: The Core. Belmont,CA: Thomson Wadsworth. 2005.

[25] Skogan W. Advocate: The promise of community policing. Chicago: Oxford University Press. 2006.

[26] Skogan WG, Hartnett SM. Community policing: Chicago style. New York: Oxford University Press. 1998.

[27] Skogan WG, Steiner L. Community policing in Chicago, Year ten. Chicago:Illinois Criminal Justice Information Authority. 2004.

[28] Skolnick JH, Bayley D. Community policing: Issues and practices around the World. National Institute of Justice: Office of Communication and Research Utilization. 1988.

[29] Tilley N. Community policing, Problem-oriented policing and intelligence-led policing. In Newburn, T. (Ed.). Handbook of policing. Cullompton: Willan Publishing. 2003.

[30] Tuffin R. The national reassurance policing programme: A six-site evaluation.Home Office Research Findings 272 : United Kingdom. 2006.

[31] Ugwuoke CU. Criminology: Explaining crime in the Nigerian context. Great AP Express Publishers; 2010 Feb..

[32] Virta S. Community policing. In Muncie, J., \& Mclaughlin, E. (Eds.). The sage dictionary of criminology. London: Sage Publications. 2006; 1-563.

[33] Walker S. Police accountability: The role of citizen oversight. Belmont, CA: Wadsworth. 2001.

[34] Zhao J, Thurma QC. Facilitators and obstacles to community policing in rural America. In Thurma, Q.C., \& McGarrel, E. F. (Eds.). Community policing in a rural setting. Cincinnati, OH: Anderson Publishing. 2006; 29-34. 